\title{
Determinable Fees and Fees Upon Conditions Subsequent in California
}

$\Gamma_{\text {HE }}$ determinable fee has recently been accorded judicial recognition in California. ${ }^{1}$ The limitation in question did not have the medieval flavor of Blackstone's well known example in which the estate was to continue until the grantee and his heirs should cease to be "tenants of the manor of Dale," 2 nor was it more than remotely reminiscent of other classical illustrations, such as, "as long as the Church of St. Paul stands," 3 or "as long as such a tree shall grow." \& More typical of the present industrial age, the document with which the California Supreme Court was concerned was a so-called oil and gas lease and the particular phraseology productive of the determinable fee was that after the expiration of a specified term the lease should continue "so long thereafter as gas and oil .... is produced therefrom in quantities sufficient to pay." "The estates created by such leases," the court said, "are freehold estates in the nature of determinable fees." 5

Thus another state has been definitely added to the list of eighteen others in which one of the most eminent authorities on the subject, writing over a decade ago, says "determinable fees do exist and are recognized and dealt with as possible legal interests in realty." 6

\footnotetext{
1 Dabney v. Edwards (1935) 91 Cal. Dec. 41, 53 P. (2d) 962.

22 Bl. Com. 109.

32 Plowd. 557.

411 Co. Rep. 49a; for other examples see Challis, Real Property (3d ed. 1911) 225-260.

5 Dabney v. Edwards, supra note 1 . The case involved an action by a real estate broker for his commission under an oral agreement for procuring a buyer for certain oil and gas leases. Subdivision 5 of Section 1624 of the California Civil Code makes an agreement employing a broker to sell real property invalid unless in writing. The rule has become established in this state tbat the term "real property" as used in this section is to be given its technical common law meaning and hence does not include leasehold interests, which are chattels real. Guy v. Brennan (1923) 60 Cal. App. 452, 213 Pac. 265; Lind v. Huene (1928) 205 Cal. 569, 271 Pac. 1087. See (1928) 17 Carre. L. REv. 187. Two of the oil and gas leases the sale of which the broker had negotiated in the instant case were leases for a fixed term of years simply. For procuring a buyer for these leases, the broker was permitted to recover his commission on the basis of his oral contract of employment, provided that it should appear that this part of the contract was severable from the remainder. Two other "leases," however, contained the provision, above quoted, that they should continue so long after the specified term as oil and gas was produced in paying quantities. This was held to take them out of the leasehold class and make them determinable fees. Since they constituted "real property" in the technical sense, the broker was unable to recover his commission on the oral contract insofar as the sale of this property was concerned.

${ }^{6}$ Powell, Determinable Fees (1923) 23 CoL. L. REv. 207, 231. For subsequent cases in other states, see 1 SMMEs, The LAw of Future Interests (1935) 323-324.
} 
While certain language used in an opinion in a previous case ${ }^{\tau}$ might be thought to have given earlier recognition to determinable fees in California, a consideration of the opinion as a whole makes it fairly evident that the court was there treating the estate as a fee upon condition subsequent rather than as a determinable fee. The distinction between the two types of estates is, of course, well established.8

$\tau$ Behlow v. So. Pac. R. R. Co. (1900) 130 Cal. 16, 62 Pac. 295. In the deed in question the following provision occurred: "The conveyance of these lands is made for railroad purposes only, and, if not so used, then it is to revert to the parties of the first part." The court refers to the conveyance as creating "an estate in fee in the lands described in the coinplaint, deterninable upon the nonperformance of the condition specified." It proceeds, however, to refer repeatedly to the provision as a condition subsequent and as one providing for a forfeiture. It is improbable, therefore, that it intended, by the mere use of the word "determinable," to classify the estate as a determinable fee.

In Johnston v. City of Los Angeles (1917) 176 Cal. 479, 168 Pac. 1047, a somewhat similar provision was involved. It was treated by counsel for both parties, however, as creating a condition subsequent rather than a determinable fee, and hence was dealt with on that basis by the court. The provision was as follows: "It being also expressly understood and agreed by and between the parties hereto, tbat in case the party of the second part shall cease to use the said premises for the said purposes of the erection and maintaining of said dam, reservoir and ditch that then and in that case the said premises hereinbefore conveyed shall revert to and become the property of the said party of the first part, his heirs, executors, administrators or assigns."

Had the question been raised in either of these cases as to whether the particular language created a determinable fee rather than a fee on condition subsequent, a nice question of construction would have been presented. See Restateacent of Property (Proposed Fimal Draft, Am. L. Inst., 1936) §66A (m): "When an otherwise effective conveyance contains a clause wbich provides 'if,' or 'upon condition that,' or 'provided that' a stated event occurs, then the estate created 'shall be null and void' or 'shall revert back,' a problem in construction is . presented as to whether such conveyance creates an estate in fee simple subject to a condition subsequent or an estate in fee simple determinable. Such a conveyance more commonly manifests an intent to create an estate in fee simple subject. to a condition subsequent."

An estate occasionally called a determinable fee but not uniformly considered as belonging to that category (see Powell, op. cit. supra note 6 , at 208,231 ) was involved in the case of Victoria Hospital Association v. All Persons (1915) 169 Cal. $455,147 \mathrm{Pac}$. 124. The question was there raised as to the right of reverter or escheat of the donor of land conveyed to a charitable corporation, in the event of its dissolution. Though not deciding whether such a right exists in California, the court intimated that if it did, it was probably not assignable or devisable. For an excellent discussion of the general question as to the proper disposition of realty held by a charitable corporation at the time of its dissolution, see Turrentine, Suggestions for Revision of Provisions of The California Civil Code Regarding Future Interests (1932) 21 CALIF. L. REv. 1, at 9-14. See also Farrer, Reverter to the Donor of the Legal Fee Vested in a Dissolved Corporation (1933) 49 L. Q. REv. 240 ; STIEs, op. cit. supra note $6, \$ 185$.

8 Co. Limt. 214b; Chaliss, Real Property (3d ed. 1911) 260-261; Gray, Rule Against Perpetuities (3d ed. 1915) \$\$12, 13 ; 1 Tlffany, Real Property (2d ed. 1920) 264, 331; Allen v. Trustees of The Great Neck Free Church (1934) 240 App. Div. 206, 269 N. Y. Supp. 341, at 350, aff'd, (1934) 265 N. Y. 570, 193 N. E. 324 . 
In the case of the determmable fee, upon the happening of the stated event the estate terminates automatically by force of the limitation alone. In the fee upon condition subsequent, before the estate will end there inust be an entry or other exercise of election on the part of the person entitled to take advantage of the breach of condition.

A fact not disclosed by the court's opinion recognizing determinable fees in California is that the question whether such a fee can be created since the Statute Quia Einptores has for decades been a controversial subject anong legal writers. ${ }^{9}$ It should, furthermore, be of interest that in two relatively recent English cases the question is referred to as still unsettled. ${ }^{10}$ In this country, Professor Gray seems to have been the leading exponent of the doctrine that the Statute Quia Einptores put an end to the creation of determinable fees. His argument was substantially as follows: ${ }^{11}$ The possibility of reverter in the grantor of a determinable fee is a reversionary right. A reversionary right cannot exist without there being tenure. But the Statute Quia Einptores put an end to all tenure between a grantor and grantee in fee simple. Therefore, there can be no possibility of reverter remaining in a grantor of a fee simple, and hence there can be no determinable fee.

In answer to this contention, Mr. Challis ${ }^{12}$ and Professor Powell ${ }^{13}$ have pointed out that by its own provisions, the Statute Quia Emptores "extendeth but only to Lands holden in Foedo simpliciter," and that its application to determinable fees is not demanded by this language. The reference to lands held in fee simply, they contend, may reasonably be understood as referring only to lands held in fee simple absolute. Professor Vance ${ }^{14}$ followed with what seeins to the present writer a convincing answer to Gray's argument. He observed that the Statute Quia Einptores does not provide that there shall be no tenure between the feoffor and feoffee. "It inerely provides that the new feoffee shall hold by the old tenure of the feoffor's lord after the analogy of the familiar feoffinent by substitution. There is nothing in it to prohibit the new feoffee from also holding of his feoffor by such tenure-that is such aggregate of legal relations - as may be agreed between them." 15

9 Powell, op. cit. supra note 6.

${ }^{10}$ In re Chardon [1928] Ch. 464; In re Wells [1933] Ch. 29, at 63. See also

Farrer, Reverter to Donor on a Determinable Fee (1934) 50 L. Q. Rev. 33.

11 Gray, op. cit. supra note 8, at 24.

12 Challis (1887) 3 L. Q. Rev. 403, reprinted in Challis, Reac Property (3d

ed. 1911) App. IV, 437.

13 Powell, op. cit. supra note 6 , at 212 .

14 Vance, Rights of Reverter and The Statute Quia Emptores (1927) 36 YaLE

L. J. 593.

15 Op. cit. supra note 14 , at 605 . 
Both the letter and the spirit of the statute are thus fully carried out by the substitution of the feoffee for the feoffor to hold of the latter's lord in the latter's stead. The creation of a new and different tenure hetween feoffor and feoffee (which will justify the existence of reversionary rights in the former) in no way prejudices the feudal rights of the lord agaimst the feoffee.

\section{Rights of Entry for Breach of Condtitions Subsequent}

In the main, rights of entry for breach of conditions subsequent seem to have received orthodox treatment by the California courts. In accordance with the prevailing view, ${ }^{16}$ no express provision for re-entry or forfeiture in the event the condition is breached is required. It is sufficient that it is unequivocally stated in the conveyance that the property is conveyed or is to be held subject to the specified condition. ${ }^{17}$ However, a mere statement of the purpose for which the conveyance is made or the use to which the property is to be devoted is not sufficient to create a condition. ${ }^{18}$ Nor will a promise on behalf of the grantee to make a specified use of the property import a condition subsequent in the event of the breach of such promise. ${ }^{19}$ Furthermore, mere use of the word "condition," without provision for forfeiture or re-entry in the event of breach, is not always sufficient. The context may show that the term "condition" was not used in the technical sense. $^{20}$ The prevailing doctrine of strict construction of conditions involving a forfeiture is codified by section 1442 of the Civil Code ${ }^{2 x}$

16 See Restatedent of Property, op. cit. supra note $7, \S 66 \mathrm{~A}$, comment $\mathrm{j}$ and $\mathrm{n}$.

17 Papst v. Hamilton (1901) $133 \mathrm{Cal}$. 631, 66 Pac. 10; Quatman v. McCray (1900) 128 Cal. 285, 60 Pac. 855; Martin v. City of Stockton (1919) 39 Cal. App. 522, 179 Pac. 894.

18 Fitzgerald v. County of Modoc (1913) 164 Cal. 493, 129 Pac. 794 ("to be used as and for a county high school ground and premises, for the County of Modoc, State of California").

19 Hawley v. Kafitz (1905) 148 Cal. 393, 83 Pac. 248 ("This deed is given by the parties of the first part, and accepted by the second party, upon the express agreement of the second party to build, or cause to be built, upon the said premises within six (6) months from the date hereof a dwelling house to cost not less than fifteen hundred $(\$ 1500.00)$ dollars."); Cullen v. Sprigg (1890) 83 Cal. 56, 23 Pac. 222; Womble v. Woinble (1910) 14 Cal. App. 739, 113 Pac. 353; Shaw v. Caldwell (1911) 16 Cal. App. 1, 115 Pac. 941; Anderson v. Palladine (1918) 39 Cal. App. 256, 178 Pac. 553; Bou v. Willits (1923) 61 Cal. App. 32, 214 Pac. 519.

20 Victoria Hospital Ass'n v. All Persons (1915) 169 Cal. 455, 147 Pac. 124 ("This deed is made upon the express condition and for the consideration that the said real property hereby conveyed and the income therefrom, shall be used by the said party of the second part for benevolent purposes and in all respects in compliance with the objects for which said party of the second part is formed ..."); Cramer v. City of Sacramento (1935) 2 Cal. (2d) 432, 41 P. (2d) 543.

21 "A condition involving a forfeiture must be strictly interpreted against the party for whose benefit it is created." Car. Crv. Code \$1442. See also CaI. Crv. CoDE $\$ 1069$, providing that a grant is to be intexpreted in favor of the grantee. 
and has been applied in cases involving rights of entry for breach of conditions subsequent. ${ }^{22}$

A somewhat new rule of law, however, seems to have been made by the decision of the District Court of Appeal in Letteau v. Ellis. ${ }^{23}$ It has been a well established practice of courts of equity to deny their particular form of relief against a breach of a covenant restricting the use of land, when a change in the character of the neighborhood has rendered the end originally sought by the restriction so unattainable that its enforcement in the particular case would be inequitable. ${ }^{24}$ Whether by inadvertence or design, this doctrine seems to have been enlarged in Letteau v. Ellis into one of implied limitation (applying both in law and equity) upon the duration of either a covenant or a condition restricting the use to which land is to be put; i.e. the duration of the covenant or condition is made dependent upon the continuance of the general character of the neighborhood. The decision seems inconsistent with an earlier one of the District Court of Appeal ${ }^{25}$ and whether the principle will ultimately be accepted by the Supreme Court is, of course, problematical. The result reached, however, would seem to be eminently fair and practically desirable. ${ }^{26}$

Several other decisions of the District Court of Appeal ${ }^{27}$ also bring conditions within the operation of a rule which is perhaps more clearly applicable to restrictive covenants or equitable servitudes. Pursuant to a general plan or scheme, the owner of a tract sells a lot with covenants restricting its use. If, thereafter, he sells other lots without such restrictions, it has sometimes been held that by reason of waiver or abandoninent he is precluded from enforcing the restriction. ${ }^{28}$ The several District Court of Appeal decisions referred to, without discus-

22 Behlow v. S. P. R. R. Co., supra note 7; Quatman v. McCray, supra note 17; Reclamation District v. Van Loben Sels (1904) 145 Cal. 181, 78 Pac. 638; Hasman v. Elk Grove Union High School (1926) 76 Cal. App. 629, 245 Pac. 464.

23 (1932) 122 Cal. App. 584, 10 P. (2d) 496. See comments on case, Turrentine, op. cit. supra note 7, at 8; (1935) 48 HARv. L. REv. 1202, 1209; (1933) 17 MINN L. Rev. 227.

24 See (1927) 16 CarIf. L. Rev. 58; Hurd v. Albert (1931) 214 Cal. 15, 3 P. (2d) 545 .

25 Strong v. Shatto (1919) 45 Cal. App. 29, 187 Pac. 159.

26 With regard to restrictive covenants, legal writers have criticized the narrow rule of simply denying equitable relief where a change in the neighborhood has made the preservation of the original character of the property no longer possible, and have urged the adoption of the view that the restriction itself bas terminated. Pound, The Progress of the Law (1920) 33 Harv. L. Rev. 820-1; Ciark, Reai Covenants and Other Interests Which Run With Land (1929) 163-5. There would seem to be no valid reason why a similar implied limitation should not be made in case of conditions.

27 Brown v. Wrightman (1907) 5 Cal. App. 391, 90 Pac. 467; Hanna v. Rodeo Vallejo Ferry Co. (1928) 89 Cal. App. 462, 265 Pac. 287; Wilshire Oil Co. v. Star Petroleum Co. (1928) 93 Cal. App. 437, 269 Pac. 722; Bernstein v. Minney (1929) 96 Cal. App. 597, 274 Pac. 614.

28 See Note (1910) 28 L. R. A. (N.s.) at 709. 
sion as to possibly differentiating factors, apply the doctrine to conditions as well as to covenants. Where a general plan or scheme was originally adopted, it would seein desirable not to distinguish in this situation between the two forms of restrictions. But where, as was apparently the case in one instance, ${ }^{29}$ there never was any general plan or scheme, it would seem soinewhat doubtful whether subsequent sales without restrictions should operate to extinguish a condition. 30

Whether rights of entry for breach of conditions subsequent are subject to the restriction of the rule against perpetuities is a question as to which Enghish and American courts, as well as various legal writers, have differed. ${ }^{31}$ The English doctrine, established by the case of In re Trustees of Hollis' Hospital, ${ }^{32}$ is that the rule applies to conditions. The subsequent Law of Property Act of 1925 entrenched this doctrine by einbodying it as one of the provisions of that act. ${ }^{33}$ The American cases $^{34}$ (including a California one ${ }^{35}$ ) have, it would seem uniformly, decided to the contrary. As an able writer has pointed out, no very satisfactory reason for the result reached is advanced by these decisions. ${ }^{36}$ Perhaps accepted conveyancing practice has been to a considerable extent responsible for them. As a result, what would have been an effective check on the use of this type of clog on titles has been swept aside.

That conditions subsequent are within the policy of the rule against perpetuities, there can be but little doubt. Legislation definitely subjecting thein to the restrictions of the rule would seem eminently desirable. ${ }^{37}$ Might it not be well to go a step farther and with certain exceptions entirely abolish conditions subsequent in the case of conveyances of land in fee? ${ }^{3 s}$ While the bringing of these conditions under

\footnotetext{
29 Bernstein v. Minney, supra note 27.

30 See (1929) 3 So. CaL. L. REv. 64 for criticism of case.

31 See GRAY, op. cit. supra note 8, at 284-294; CraurIs, op. cit. supra note 8, at 187-190; 1 TIFFANY, op. cit. supra note 8, at 603; KALES, EsTATES, FUTURE INTERests aNd Ilxegal Conditions and Restraints In Illinois (2d ed. 1920) \$662.

32 [1899] 2 Ch. 540; followed in In re Da Costa [1912] $1 \mathrm{Ch} .337$.

3315 GEo. 5 , c. $20, \$ 4$ (3).

34 See SImes, op. cit. supra note $6, \$ 506$.

35 Strong v. Shatto (1919) 45 Cal. App. 29, 187 Pac. 159.

36 Snres, op. cit. supra note $6, \$ 506$.

37 See McMurray, $A$ Review of Recent California Decisions in the Law of Property (1921) 9 CAIrF. L. REv. 447, 456; Turrentine, op. cit. supra note 7, at 8.

38 The suggestion is that they be abolished in so far as the possibility of their creation by future conveyances is involved. Constitutional limitations would probably prevent the impairment of existing rights. In the event of such abolition, it would seem desirable to make exceptions applicable to conveyances of land without consideration for public or charitable purposes. In order to prevent the evasion of a prohibition against conditions subsequent by resort to a determinable fee, it might be well to include the latter (subject to the same exceptions) in any statutory prohibition. In that case, an additional exception, to permit determinable fees of the nature of the oil and gas "lease" involved in Dabney v. Edwards, supra notes 1 and 5 , might be desirable.
} 
the operation of the rule against perpetuities would invalidate many of them, it would not absolutely prevent their use. By careful wording, conditions subsequent which would be effective for many decades could still be drawn..$^{30}$ But except in the case of gifts of land for public or charitable purposes, is there any social need for the continuance of this medieval conveyancing device? A covenant, while perhaps not quite as strong a deterrent against the use sought to be prohibited, is generally effective. The pitfalls and hardships incident to a condition which may result in a forfeiture of title in fee are fairly apparent. Perhaps no great sympathy can be aroused for the original grantee who violates the conditions on which he has accepted the land; but even here, lapse of time may cause hin to forget that restrictions ever existed. Where the forfeiture falls upon the original grantee's successor who takes by gift, devise or descent and does not know that the title is subject to forfeiture in the event of use of the land for certain purposes, a situation of obvious hardship results. Conditions subsequent imposed upon ownership in fee render titles both technically and practically unmarketable and make it difficult to borrow money on mortgage security. The detriment from their retention would seem definitely to outweigh the gain.

\section{The Descent of Possibilities of Reverter AND RIGHTS OF ENTRY}

Although possibilities of reverter and rights of entry were at common law considered mere possibilities and not estates, and hence not assignable or devisable, ${ }^{40}$ there was no doubt that they passed to the heirs of the feoffor or grantor by whom the interest was originally created. But whether the heirs took technically by descent, or by representation, is the subject of considerable difference of modern judicial opinion. ${ }^{11}$ Due to the common law rules for tracing descent, the question was formerly of little importance. The same persons would usually be entitled whether they took by descent or by representation. At common law, descent was traced from the person last seised or from the first

${ }^{39}$ Cf. In re Villar [1928] Ch. 471, [1929] 1 Ch. 243. A will provided for the vesting of certain interests at the expiration of twenty years after the day of the death of the last survivor of the lineal descendants of Queen Victoria living at the testator's death. It was held that the rule against perpetuities had not been violated by this provision.

40 Challis, op. cit. supra note 8 , at 228, n. $76 ; 1$ TIFraNy, op. cit. supra note 8 , at $313-316,474$; GRAy, op. cit. supra note 8, at 7. As to possibilities of reverter, however, perhaps the weight of modern authority is in favor of transferability. See Restatenent of Property (Explanatory Notes, Tentative Draft No. 4, Ain. L. Inst., 1933) $\$ 200$ (I), pp. 107-112; 1 TIFFANY, op. cit. supra note 8 , at $474, \pi$. 27; 3 SInIEs, op. cit. supra note 6, 159; (1918) 18 Cor. L. Rev. 84.

41 See Sternberg, The Nature of Possibilities of Reverter (1931) 6 Notre DAME Law. 442; (1931) I7 VA. L. Rev. 402; Srares, op. cit. supra note 6, $\$ 724$. 
purchaser. ${ }^{42}$ On the death of $A$, the feoffor or grantor in whom a possibility of reverter or contingent right of entry originally existed, this interest passed, of course, to $B$, his heir. But if $B$ died before the right ripened into a possessory interest, and such right passed by descent, like a reversion, remainder or other executory interest, $A$ and not $B$ was the one froin whom descent would be traced. The person who would have been the heir of $A$, had the latter died the instant after $B$, would be the one entitled. In other words, whenever the mere possibility became a right of possession, it would be exercisable by those who at that time answered the description of heirs of the person originally entitled. But exactly the same result would follow from the view that no interest ever passed by descent from the one originally entitled but that when the right to possession accrued, it was enforceable on his bchalf by his legal representatives, i.e. by those who answered the description of his heirs at that time. ${ }^{43}$

The prevailing form of modern statute, however, provides for the tracing of descent from the person last entitled, regardless of whether he was seised, or whether he acquired the land by purchase or descent. ${ }^{44}$ Under these statutes, the persons entitled may be very different, according as they take by descent or by representation. By descent, the right originally passing from $A$ to $B$, will, on $B$ 's death, go to $B$ 's heir, not to the one who would then be the heir of $A$. Thus when a mere possibility ripens into a possessory right, the person "entitled may have no relationship with $A$, the grantor, in whoin the right originally existed. 45

124 KeNT, CoMng. (12th ed. 1873) 385-389; Chaldrs, op. cit. supra note 8 , at $238 ; 2$ TIFFANY, op. cit. supra note 8 , at 1890-93; KaIEs, op. cit. supra note 31 , $\$ 380$.

43 See authorities cited infra notes 46-49.

412 TIFFANY, op. cit. supra note 8, at 1891; Kales, op. cit. supra note 31, \$381; KENT, op. cit. supra note 42 , at 388 . follows:

45 Specific examples under the existing California succession statutes are as

(1) A possibility of reverter or right of entry originally held by $X$ might pass by descent, first to $X$ 's son $Y$ (CAL. Prob. CoDe \$222) and then from $Y$ to $Y$ 's wife $Z$ (CAL. Prob. Code $\$ 224$ ), and be held by $Z$ wben the right of possession accrued. But $Z$ would not answer the description of $X$ 's heir at that time, and hence would not be entitled to take by representation as distinguished from descent.

(2) A possibility of reverter or right of entry originally held by $X$ might pass by descent, first to $X$ 's nephew $Y$, the son of $X$ 's deceased brother (CAz. ProB. CODE $\$ 225$ ), and then from $Y$, to $Y$ 's mother, $Z$ (CAI. ProB. CODE $\$ 225$ ), and be held by $Z$ when the right of possession accrued. But $Z$ would not answer the description of $X$ 's heir at that time, and bence would not be entitled to take by represention as distinguished from descent.

Numerous additional examples might be given. In certain instances, of course, the right might pass to the same person both by descent and by representation, e.g., it might descend from $X$ to his son, $Y$, and from $Y$ to $Y^{\prime} s$ son, $Z$, who would hold wben the right of possession accrued. Here, $Z$ would also take by representation from $X$, as answering the description of his heir at that particular time. 
Apparently the first reported judicial pronouncement of the "representation" theory occurred in the decision of the New York Court of Appeals in 1896 in Upington v. Corrigan. ${ }^{46}$ In two very much earlier South Carolina cases, ${ }^{47}$ however, it had been held that the possibility of reverter after the old conditional fee simple (which existed in South Carolina since it had been held that the statute of $D e$ Donis was not there in force) passed to the heirs of the grantor at the time the conditional fee determined rather than to his heirs at the time of his death. This holding, however, was not made upon any theory that the imterest passed by representation rather than by descent, but on the ground that the common law rule of tracing descent from the person last seised, or from the first purchaser, had not been altered in South Carolina as to this particular type of future interest. As far as the descent statutes of that state were concerned, the court took the position that the interest in question "is not regarded as property, it is a mere possibility analogous in some degree to an heir apparent's right of succession." 48 The latter analogy may perhaps have suggested the "representation" theory subsequently advanced in Upington v. Corrigan and other cases.

The precise question which confronted the New York court in Upington v. Corrigan was whether a right of entry for breach of condition passed to the heirs or to the devisee of the original grantor. There was no doubt that in the absence of a will such a right would pass to the heirs. But a New York statute provided that "every estate and interest in real property descendible to heirs may be devised." This statute was made the basis for the contention that the right passed to the devisee. The court decided otherwise, however, holding that since rights of this character did not technically descend to the heirs, the statute in question did not permit such rights to be devised. This New York decision has apparently been the basis for sinilar holdings in other states. ${ }^{49}$

46 (1896) 151 N. Y. 143, 45 N. E. 359, 37 L. R. A. 794. The court said: "To those rights her heirs, after her decease, succeeded, by force of representation, and not by descent. There was no estate upon which the statute of descents could operate; but, as heirs, there devolved upon them the bundle or aggregate of rights which resided in and survived the death of the grantor, their ancestor. Her legal personality was continued in them."

47 Adams v. Champlin (1833) 1 Hill. Eq. (S. C.) 265; Deas v. Ḧorry (1835) 2 Hill Eq. (S. C.) 244.

$48 \mathrm{Ibid}$. at 248.

49 Puffer v. Clark (1918) 202 Mich. 169, 199, 168 N. W. 471, 480: "According to what seems the better reasoning, a possibility of reverter is not devisable, but passes to those who are the heirs of the grantor at the time of the breach. ... It passes by right of representation and not by descent to the heirs at the time of the breach." Ashuelot National Bank v. City of Keene (1907) 74 N. H. 148, 65 Atl. 826, 9 L.R.A. (N.S.) 758: "The theory of the common law was ... that he had a mere 
Probably the decision most frequently cited for the contrary conclusion, i.e. that the interests in question pass by descent and not by representation, is that of the Illimois Supreme Court in North $v$. Graham.0 It is not clear, however, that in this case the court was considering the specific question whether the possibility of reverter passed to the heirs by descent or by representation. Nowhere in its opinion does it refer to that distinction. It seems rather to assume that the reason at common law a possibility of reverter, as well as a reversion, passed to those who were the original grantor's heirs at the time the interest ripened into a right to possession, was the common law rule that descent must be traced from the person last seised; and, therefore, with the statutory abolition of this method of tracing descent, it naturally concluded that a possibility of reverter, like a reversion, now passed by descent to those who were the original grantor's heirs at the time of his death. A more specific consideration of the question seems to have been made by the Supreme Court of Appeals of Virginia in Copenhaver v. Pendleton. ${ }^{51}$ The court there arrived at the definite conclusion that at common law possibilities of reverter did not pass by representation but by descent, in the same unanner as reversions, remainders and executory interests. Therefore the provisions of the Virginia statutes changing the method of tracing descent applied to these, just as to other rights or imterests. ${ }^{52}$

possibility, capable of being exercised by him in his life-time if the condition was broken, or by his heir upon whom, after his decease, it devolved as his representative, and not by way of inheritance." See also Methodist Protestant Church v. Young (1902) 130 N. C. 8, 40 S. E. 691; Atkins v. Gillespie (1927) 156 Tenn. 137, 299 S. W. 776 .

50 (1908) 235 Ill. 178, 85 N. E. 267, 18 L. R. A. (N. S.) 624, 126 Am. St. Rep. 189. In its opinion the court said: "Did the land in question revert or descend to the grantor's heirs who were in existence at the time of his death, or to his heirs who were in existence at the time the fee in question terminated? ... The right or interest reserved by the deed in question to the grantor and his heirs must have been in some one between the death of the original grantor, Adain Stewart, and the determination of the estate when the property ceased to be used and occupied as a church. It is an interest that is inherited, and, therefore, inust have been cast by descent upon Adam Stewart's heirs at the time of his death, and did not originate at the time the property ceased to be used for church purposes."

51 (1930) 155 Va. 463,155 S. E. 802,77 A. L. R. 324.

52 The court said: "... We are of opimion ... that at common law a possibility of reverter is an inheritable right which passed by descent cast to the person who at the time of the happening of the contingency upon which it depended then answered the description of heir of the creator of the fee upon the determination of which it depended, and that such person took as beir and not by representation. ... in Virginia, upon the death intestate of the creator of a fee after which there is a possibility of reverter, such possibility of reverter immediately descends by inheritance to the person or persons designated by the Virginia statutes of descent ... as those to whom his real estate of inheritance shall descend, who may :.. transmit it by inheritance to his or their heirs in accordance with the Virginia statutes of descent." Copenhaver v. Pendleton, supra note 51, at 496, 497, 155 S. E. at 812,813 . 
The decisions in California have apparently never dealt with the question as to whether possibilities of reverter and rights of entry pass to the heirs by descent or by representation..$^{53}$ The problem is of more than theoretical importance. As has been pointed out, the persons entitled under the one theory or the other may be entirely different individuals. ${ }^{54}$ One may be confronted with the question practically, not only in cases where the mere possibility has ripened into a right to possession which is being asserted, but also in situations where a release of the contingent right is sought. Although independently of statute a possibility of reverter or right of entry may not be assignable or devisable, ${ }^{55}$ apparently without exception the cases recognize that these contingent rights may be released, either by the original grantor or by his heirs. ${ }^{56}$ But are the latter the persons who have taken by descent, or are they those who at the time the release is made answer the description of heirs of the original grantor? The persons from whoin the release must be obtained may differ entirely, according as the one theory or the other is applied for their ascertainment. Until the question is definitely settled in California a careful conveyancer in effecting a release of a condition or possibility of reverter, should in certain instances, procure the requisite docuinents from two groups of individuals, namely, from those to whom such contingent interest

53 In Pavkovich v. So. Pac. R. R. Co. (1906) 150 Cal. 39, 49, 87 Pac. 1097, 1100 , the owner of a tract of land had made a deed conveying a railroad right of way and an additional seven acre piece for the purpose of supplying rock therefrom for railroad purposes. The deed also contained a condition subsequent forfeiting the property granted, in case a railroad should not be constructed within a specified time or in the event it should be abandoned. The action was by a successor in interest of the grantor to enjoin removal of rock for other than railroad purposes. The coinplaint alleged that plaintiff was the owner of the land described in the deed in question " 'subject only to the terms and provisions' of the said deed." In answer to the contention that the complaint did not show that the plaintiff was an heir or assign of the original grantor, the court said that this allegation in the complaint ineant "that he is the owner of all the estate and rights reserved therein to the grantors. He could only become such owner by descent or purchase from the grantors or their successors in interest." There is no indication, however, that in using the word "descent" the court had in mind the technical distinction between taking by descent and taking by representation.

54 Supra note 45 .

55 Supra note 40.

501 TrFFANY, op. cit. supra note 8, at 295, 474-5. Even when the heirs take by lepresentation and not by descent, it is held that those who answer the description of heirs of the grantor at the time the release is executed and who would be entitled to the estate had a breach actually occurred may execute an effective release. Atkins v. Gillespie, supra note 49, commented on in (1928) 12 ManN. L. REv. 767; Trustees of Calvary Presbyterian Church v. Putnam (1928) 249 N. Y. 111, 162 N. E. 601, commented on in (1929) 27 Mrch. L. REv. 346; (1928) 8 ORE. L. REv. 86; (1928) 3 ST. J. L. REv. 124; (1928) 37 YaIE L. J. 530. 
may have passed by descent and from those who may be entitled to execute a release on the theory of representation. ${ }^{57}$

It would seem that a strong case may be made in support of the conclusion that in California a contingent right of entry for breach of condition (as distinguished from a possibility of reverter after a determinable fee) does not pass by representation but by descent to the heirs at the time of death, in the same manner as any other property right. By express provision of Civil Code section 1046 such contingent right may be transferred; and this, the Supreme Court has held, makes the right devisable as well as assignable. ${ }^{58}$ So material a change, therefore, in the incidents of a right of entry would seem ample justification for its removal froin the category of bare "possibilities" and its inclusion withm the term "property" as used in sections 201 and 220 of the Probate Code dealing with succession. ${ }^{59}$ The provisions of Civil Code sections $699,{ }^{60} 700,{ }^{61} 1044^{62}$ and $1045,{ }^{63}$ when read in connection with section 1046, tend to support the same conclusion.

As a possibility of reverter is so similar in nature to a right of entry, ${ }^{64}$ even in the absence of a specific provision for its assignability it would not be unreasonable to hold that Civil Code section 1044, when interpreted in the light of the other three sections above mentioned, makes it, also, an assignable and devisable property right, and hence one which passes by descent. From a practical standpoint, any differentiation in the manner of succession to rights of entry and possibilities of reverter, as compared with property in general, would seem to be something properly to be avoided. If these rights pass by representation rather than by descent, in numerous situations probate proceedmgs cannot be relied upon to designate the persons entitled. ${ }^{65}$

$$
\text { W.W. Ferrier, Jr. }
$$

SCHOOL OF JURISPRUDENCE,

UNTVERSITY OF CALIFORNIA.

\footnotetext{
57 Supra note 45.

58 Johnston v. City of Los Angeles (1917) 176 Cal. 479, 168 Pac. 1047.

59 "Upon the death of either husband or wife, one-half of the community property belongs," etc. (CAL. PROB. CODE \$201). "The separate property of a person who dies without disposing of it by will is succeeded to," etc. (CAL. Prob. Code \$220).

60 "Future miterests pass by succession, will, and transfer, in the same manner as present interests." CAL. Crv. CODE $\$ 699$.

61 "A mere possibility, such as the expectancy of an heir apparent is not to be deemed an interest of any kind." CaL. Crv. CoDe $\$ 700$.

62 "Property of any kind may be transferred, except as otherwise provided by this article." CaI. Crv. Code $\$ 1044$.

63 "A mere possibility, not coupled with an interest, cannot be transferred." Car. Crv. Code $\$ 1045$.

ot See 1 Frazer, Cases and Readings on Property 199 n.; Bordwell, The Common Law Scheme of Estates (1933) 18 IA. L. REv. 425, 443.

65 See examples given supra note 45 .
} 